技術報告

แแแแแแแแแแแแแแแแแแแแแแแแแแ

\title{
骨腫瘍患者における血中オステオカルシンの 臨床的意義について
}

\author{
鳥住和民, 上好昭孝*, 安井昌之**, 清水映二***, \\ 岡本幸春 $* * *$, 津田忠昭 $* * *$, 大田喜一郎 $* * *$ \\ 和歌山県立医科大学放射線科, *同大学整形外科, \\ $* *$ 同大学神経科, $* * *$ 同大学検査診断学講座 \\ 640 和歌山市七番丁 1 \\ 1988年 1 月 18 日 受理
}

Key Words: bone tumor, osteocalcin, radioimmunoassay

\section{1. はじめに}

骨腫揚によってもたらされる正常骨での骨吸収の機 序として，(1)正常な骨を融解させる物質の腫瑒からの 産生，(2)腫瘍による正常周辺部骨での破骨細胞の活発 化，(3腫瘍より産生された物質による血液前駆細胞の 破骨細胞への移行，(4)正常骨を支配する血管系への腫 瘍の圧迫，などが考えられる。最近の報告では，覀性 腫瘍に拈いては高カルシウム (Ca) 血症を伴う症例が 10\%前後みられ")，また，骨からの Ca 動員作用として local osteolytic hypercalcemic $(\mathrm{LOH})^{2,3)}$ や humoral hypercalcemic of malignancy (HHM)の因子 ${ }^{4)-7)}$ が関 与するといわれている。

一方, Price らは骨芽球由来の bone Gla 蛋白であ るオステオカルシンが骨代謝の生化学的な指標として 有用であると報告し ${ }^{8)}$ ，著者らも腎不全透析患者" 慢性関節リューマチ患者 ${ }^{10)}$, 骨粗鬆症患者 ${ }^{11}$ 亿おける 骨回転の生化学的指標になり得るとの成績を得てい る。

以上のことから考えて，骨腫場患者においても直接 的あるいは間接的に骨回転を刺激し, 骨芽球の産生蛋 白であるオステオカルシンの合成を穴進させる可能性 がある。

そこで, 今回は血中オステオカルシンの測定が骨腫 瘍患者の生化学的な指標になり得るか否かについて検 討を加えたので報告する。

\section{2. 対象および方法}

検索の対象は骨腫湯患者56例で, その内訳は転移性
骨腫瘍26例, 骨髄腫 9 例, 軟骨肉腫 8 例, 巨細胞腫 5 例である。

血中オステオカルシンは Compagnie ORIS Industrie S.A. 社製の kit を, c- $\mathrm{PTH}_{65-84}$ は INC 社製 kit そして生化学的検查はオートアナライザを用いて測定 を行い, 平均值については mean \pm SEM で表示した。 な拉, 測定検体は早朝空腹時に採血し, 遠心分離後 ー20 C にて保存した。また，これらの骨腫瘍患者の 腎機能は血中クレアチニン $1.2 \mathrm{mg} / \mathrm{dl}$ 以下とすべて正 常であった。

\section{3. 結 果}

転移骨腫瘍, 骨髄腫, 軟骨肉腫, 骨肉腫叔よび巨細 胞腫飞抢ける血中 $\mathrm{Ca}$, 補正 $\mathrm{Ca}\left({ }^{\prime} \mathrm{Ca}\right)^{12)}, \mathrm{P}, \mathrm{Cl}, \mathrm{Cl} / \mathrm{P}$ 比, ALP, LDH, c-PTH $\mathrm{P}_{65-84}$, オステオカルシンの諸 成績を示し比較検討した（Table 1, Fig. 1)。

Table 1 に示すごとく, 軟骨肉腫と巨細胞腫では血 中 $\mathrm{P}$ の濃度は低く, 逆に $\mathrm{Cl} / \mathrm{P}$ 比は高くなる傾向とな った。一方, 転移性骨腫瘍, 骨髄腫そして骨肉腫では 血中 $\mathrm{P}$ 濃度は高く高 $\mathrm{P}$ 血症を呈する成績が得られた。

また，血中 ALP は転移性骨腫瘍と骨髄腫において 高く, 血中 LDH は転移性骨腫場で高值を示した。

つぎに血中オステオカルシンについてみると，これ ら骨腫瘍患者のオステオカルシンの值は健康人の 4.10 $\pm 0.17 \mathrm{ng} / \mathrm{ml}$ (mean $\pm \mathrm{SEM})$ に比べ高くなる傾向を 示し,なかでも転移性骨腫痶, 骨髄腫, 巨細胞腫で著 明な高值を認めた。

Table 2 亿, 各種骨腫瘍疾患群の間に沶いて有意差 の存在した血中 $\mathrm{P}, \mathrm{Cl} / \mathrm{P}$ 比, ALP, オステォカルシン 
Table 1 Levels of $\mathrm{Ca}$, ' $\mathrm{Ca}, \mathrm{P}, \mathrm{Cl}, \mathrm{Cl} / \mathrm{P}$ ratio, $\mathrm{ALP}, \mathrm{LDH}, \mathrm{c}-\mathrm{PTH}_{65-84}$ and osteocalcin in sera of the patients with bone metastasis, myeloma, chondrosarcoma, osteosarcoma and giant cell tumor

\begin{tabular}{|c|c|c|c|c|c|c|c|}
\hline & & $\begin{array}{c}\text { Bone } \\
\text { metastasis } \\
(n=26)\end{array}$ & $\begin{array}{c}\mathrm{B} \\
\text { Myeloma } \\
(n=9)\end{array}$ & $\begin{array}{c}\mathrm{C} \\
\text { Chondro } \\
\text {-sarcoma } \\
(n=8)\end{array}$ & $\begin{array}{c}\quad \mathrm{D} \\
\text { Osteo } \\
\begin{array}{c}\text {-sarcoma } \\
(n=8)\end{array}\end{array}$ & $\begin{array}{c}\mathrm{E} \\
\text { Giant cell } \\
\text { tumor } \\
(n=5)\end{array}$ & $\begin{array}{l}\text { Healthy } \\
\text { control }\end{array}$ \\
\hline $\mathrm{Ca}$ & ) & $9.42 \pm$ & $9.72 \pm$ & $9.18 \pm$ & $9.30 \pm 0.24$ & $9.36 \pm 0.22$ & $8.2-10.0$ \\
\hline 'Ca & $(\mathrm{mg} / \mathrm{dl})$ & $10.05 \pm 0.18$ & $9.94 \pm 0.04$ & $9.81 \pm 0.22$ & $9.30 \pm 0.26$ & $9.46 \pm 0.24$ & $8.2-10.0$ \\
\hline $\mathrm{P}$ & $(\mathrm{mg} / \mathrm{dl})$ & $3.49 \pm 0.13$ & $4.86 \pm 0.03$ & $2.66 \pm 0.86$ & $3.73 \pm 0.22$ & $2.78 \pm 0.16$ & $2.3-4.1$ \\
\hline $\mathrm{Cl}$ & $(\mathrm{mEq} / \mathrm{l})$ & $102.96 \pm 0.16$ & $105.56 \pm 0.96$ & $102.29 \pm 1.20$ & $102.13 \pm 1.43$ & $105.26 \pm 1.02$ & $98-107$ \\
\hline $\mathrm{Cl} / \mathrm{P}$ ratio & & $30.60 \pm 1.16$ & $29.88 \pm 2.36$ & $45.14 \pm 8.94$ & $27.93 \pm 1.34$ & $38.38 \pm 2.32$ & $26.1-42.6$ \\
\hline ALP & $(\mathrm{IU} / 1)$ & $407.48 \pm 75.75$ & $317.89 \pm 83.81$ & $185.57 \pm 28.16$ & $252.50 \pm 108.04$ & $101.80 \pm 26.51$ & $100-280$ \\
\hline LDH & $(\mathrm{lU} / \mathrm{l})$ & $466.42 \pm 105.54$ & $307.50 \pm 32.28$ & $273.14 \pm 31.21$ & $159.03 \pm 79.79$ & $207.40 \pm 51.78$ & $220-460$ \\
\hline c- $\mathrm{PTH}_{65-84}$ & $\mathrm{ng} / \mathrm{ml})$ & $0.40 \pm 0.03$ & $0.40 \pm 0.05$ & $0.32 \pm 0.05$ & $0.30 \pm 0.26$ & $0.53 \pm 0.24$ & $0.6 \downarrow$ \\
\hline Osteocalcin & (ng/ml) & $9.10 \pm 0.98$ & $9.13 \pm 1.51$ & $5.75 \pm 0.32$ & $5.37 \pm 0.07$ & $7.97 \pm 0.12$ & $0.6-7.5$ \\
\hline
\end{tabular}

mean \pm SEM

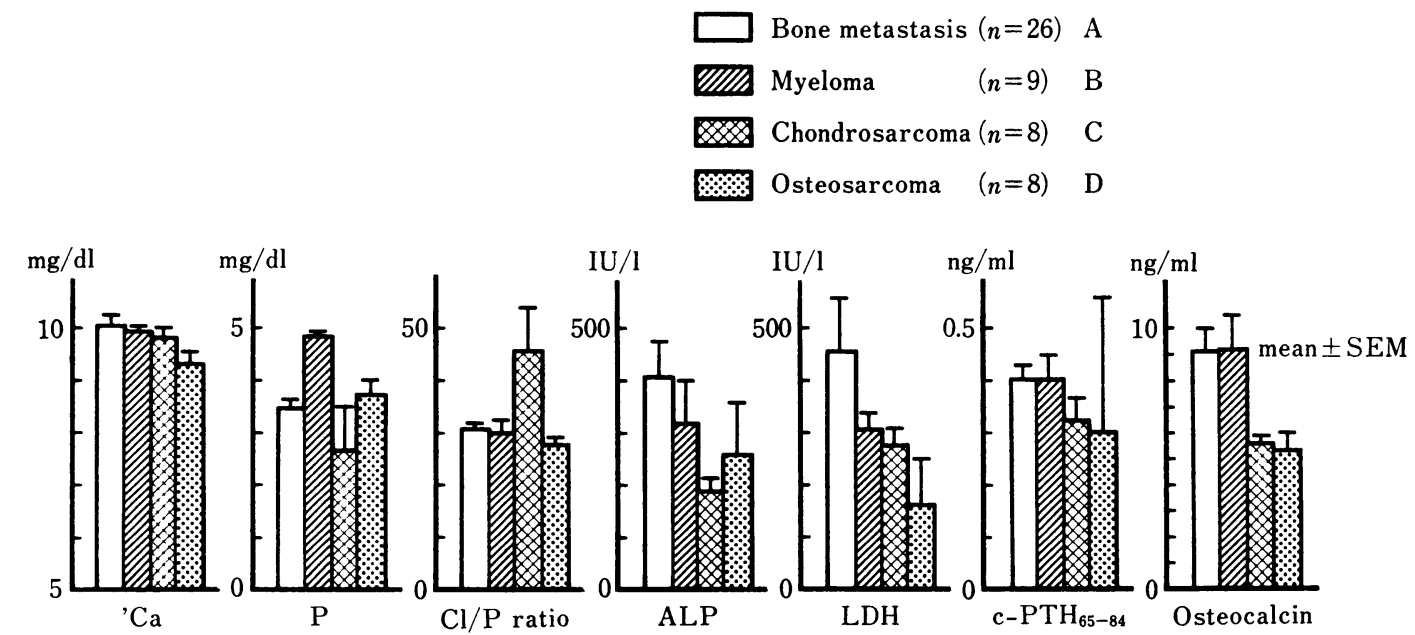

Fig. 1 Levels of ' $\mathrm{Ca}, \mathrm{P}, \mathrm{Cl} / \mathrm{P}$ ratio, ALP, LDH, c-PTH ${ }_{65-84}$ and osteocalcin in sera of bone metastasis, myeloma, chondrosarcoma and osteosarcoma.

Table 2 Pair-matched significances in $\mathrm{P}, \mathrm{Cl} / \mathrm{P}$ ratio, ALP, $\mathrm{LDH}$ and osteocalcin in sera of $\mathrm{A}, \mathrm{B}, \mathrm{C}, \mathrm{D}$ and $\mathrm{E}$ groups

\begin{tabular}{cccccccccc}
\hline \multicolumn{2}{c}{$p$} & \multicolumn{2}{c}{$\mathrm{Cl} / \mathrm{P}$ ratio } & \multicolumn{2}{c}{ ALP } & \multicolumn{2}{c}{ LDH } & \multicolumn{2}{c}{ Osteocalcin } \\
\hline $\mathrm{A}<\mathrm{B}$ & $p<0.001$ & $\mathrm{~A}<\mathrm{C}$ & $p<0.001$ & $\mathrm{~A}>\mathrm{C}$ & $p<0.01$ & $\mathrm{~A}>\mathrm{B}$ & $p<0.01$ & $\mathrm{~A}>\mathrm{C}$ & $p<0.001$ \\
$\mathrm{~A}>\mathrm{C}$ & $<0.001$ & $\mathrm{~A}<\mathrm{E}$ & $<0.01$ & $\mathrm{~A}>\mathrm{D}$ & $<0.05$ & $\mathrm{~A}>\mathrm{C}$ & $<0.001$ & $\mathrm{~A}>\mathrm{D}$ & $<0.001$ \\
$\mathrm{~A}>\mathrm{E}$ & $<0.001$ & $\mathrm{~B}<\mathrm{C}$ & $<0.01$ & $\mathrm{~A}>\mathrm{E}$ & $<0.001$ & $\mathrm{~A}>\mathrm{D}$ & $<0.001$ & $\mathrm{~A}>\mathrm{E}$ & $<0.01$ \\
$\mathrm{~B}>\mathrm{C}$ & $<0.001$ & $\mathrm{C}>\mathrm{D}$ & $<0.01$ & & & $\mathrm{~A}>\mathrm{E}$ & $<0.01$ & $\mathrm{~B}>\mathrm{C}$ & $<0.001$ \\
$\mathrm{~B}>\mathrm{D}$ & $<0.01$ & $\mathrm{C}>\mathrm{E}$ & $<0.05$ & & & & & $\mathrm{~B}>\mathrm{D}$ & $<0.001$ \\
$\mathrm{~B}>\mathrm{E}$ & $<0.001$ & & & & & & & $\mathrm{~B}>\mathrm{E}$ & $<0.05$ \\
$\mathrm{C}<\mathrm{D}$ & $<0.001$ & & & & & & & $\mathrm{C}<\mathrm{E}$ & $<0.05$ \\
$\mathrm{D}>\mathrm{E}$ & $<0.01$ & & & & & & & $\mathrm{D}<\mathrm{E}$ & $<0.05$ \\
\hline
\end{tabular}


Table 3 Levels of $\mathrm{Ca}$, 'Ca, $\mathrm{P}, \mathrm{Cl}, \mathrm{Cl} / \mathrm{P}$ ratio, $\mathrm{ALP}, \mathrm{LDH}, \mathrm{c}-\mathrm{PTH}_{65-84}$ and osteocalcin in sera of hypercalcemic and normocalcemic patients with bone metastasis caused by various origins of cancers

\begin{tabular}{lccc}
\hline & & $\begin{array}{c}\text { Hypercalcemic } \\
(n=8)\end{array}$ & $\begin{array}{c}\text { Normocalcemic group } \\
(n=18)\end{array}$ \\
\hline $\mathrm{Ca}$ & $(\mathrm{mg} / \mathrm{dl})$ & $10.18 \pm 0.50$ & $9.18 \pm 0.12^{*}$ \\
$\mathrm{C} C$ & $(\mathrm{mg} / \mathrm{dl})$ & $11.04 \pm 0.32$ & $9.53 \pm 0.07^{* *}$ \\
$\mathrm{P}$ & $(\mathrm{mg} / \mathrm{dl})$ & $3.68 \pm 0.22$ & $3.33 \pm 0.17$ \\
$\mathrm{Cl}$ & $(\mathrm{mEq} / \mathrm{l})$ & $102.63 \pm 1.44$ & $102.73 \pm 0.92$ \\
$\mathrm{Cl} / \mathrm{P}$ ratio & & $28.56 \pm 1.57$ & $31.48 \pm 1.81^{*}$ \\
$\mathrm{ALP}$ & $(\mathrm{lU} / \mathrm{l})$ & $644.71 \pm 134.40$ & $326.47 \pm 99.30^{* *}$ \\
$\mathrm{LDH}$ & $(\mathrm{lU} / \mathrm{l})$ & $925.83 \pm 244.17$ & $254.38 \pm 29.63^{* *}$ \\
$\mathrm{c}-\mathrm{PTH} \mathrm{H}_{65-84}$ & $(\mathrm{ng} / \mathrm{ml})$ & $0.38 \pm 0.04$ & $0.41 \pm 0.05$ \\
$\mathrm{Osteocalcin}(\mathrm{ng} / \mathrm{ml})$ & $11.63 \pm 1.88$ & $7.14 \pm 0.97^{* *}$ \\
\hline
\end{tabular}

Table 4 Levels of $\mathrm{Ca},{ }^{\prime} \mathrm{Ca} \mathrm{P}, \mathrm{Cl}, \mathrm{Cl} / \mathrm{P}$ ratio, $\mathrm{ALP}, \mathrm{LDH}$, c- $\mathrm{PTH}_{65-84}$ and osteocalcin in sera of hypercalcemic and normocalcemic patients with myeloma

\begin{tabular}{lccc}
\hline & & $\begin{array}{c}\text { Hypercalcemic } \\
(n=3)\end{array}$ & $\begin{array}{c}\text { Normocalcemic group } \\
(n=6)\end{array}$ \\
\hline $\mathrm{Ca}$ & $(\mathrm{mg} / \mathrm{dl})$ & $10.74 \pm 0.36$ & $9.08 \pm 0.36^{*}$ \\
$\mathrm{C} \mathrm{Ca}$ & $(\mathrm{mg} / \mathrm{dl})$ & $11.10 \pm 0.56$ & $9.28 \pm 0.21^{* *}$ \\
$\mathrm{P}$ & $(\mathrm{mg} / \mathrm{dl})$ & $4.08 \pm 0.79$ & $3.58 \pm 0.24^{*}$ \\
$\mathrm{Cl}$ & $(\mathrm{mEq} / \mathrm{l})$ & $104.33 \pm 1.21$ & $105.60 \pm 1.36$ \\
$\mathrm{Cl} / \mathrm{P}$ ratio & & $28.67 \pm 6.96$ & $30.08 \pm 2.19$ \\
$\mathrm{ALP}$ & $(\mathrm{IU} / \mathrm{l})$ & $476.67 \pm 233.29$ & $208.60 \pm 45.50^{* *}$ \\
$\mathrm{LDH}$ & $(\mathrm{IU} / \mathrm{l})$ & $372.33 \pm 23.54$ & $263.50 \pm 25.94^{*}$ \\
$\mathrm{c}-\mathrm{PTH} \mathrm{H}_{65}-84$ & $(\mathrm{ng} / \mathrm{ml})$ & $0.47 \pm 0.06$ & $0.36 \pm 0.08^{*}$ \\
$\mathrm{Osteocalcin}(\mathrm{ng} / \mathrm{ml})$ & $13.13 \pm 2.96$ & $7.18 \pm 1.43^{* *}$ \\
\hline
\end{tabular}

について記載した。

転移性骨腫瘍について, 補正 Ca ('Ca) $10 \mathrm{mg} / \mathrm{dl}$ 以 上の群とそれ未満の群に分類し, $\mathrm{Ca}, \mathrm{P}, \mathrm{Cl}, \mathrm{Cl} / \mathrm{P}$ 比, $\mathrm{ALP}, \mathrm{LDH}, \mathrm{c}-\mathrm{PTH}_{65-84}$, オステオカルシンの括のお のの值を比較検討したところ, 高 $\mathrm{Ca}$ 血症群では $\mathrm{Ca}$, ALP，LDH，オステオカルシンにおいて高值を，また $\mathrm{Cl} / \mathrm{P}$ 比に拉いて低值となることが認められた（Table 3)。

同様に骨髄腫について分類し比較してみたところ, 'Ca が $10 \mathrm{mg} / \mathrm{dl}$ 以上の群は $10 \mathrm{mg} / \mathrm{dl}$ 末満の群に比 ベ, $\mathrm{Ca}, \mathrm{P}, \mathrm{ALP}, \mathrm{LDH}, \mathrm{c}-\mathrm{PTH}_{65-84}$, オステオカルシ ンの值に拈いて，有意に高くなることが示された (Table 4 )。

\section{4. 考案および結語}

Bone Gla 蛋白は骨芽細胞から産生され骨回転の指
標として有用であることが Price により報告され 著者らも腎不全透析患者 ${ }^{9)}$ ，慢性関節りューマチ患 者 ${ }^{10)}$ ，骨粗鬆症患者 ${ }^{11}$ 亿応用し同様の知見を得てい る。

骨腫瘍患者に拈いては，腫瘍細胞から産生される骨 融解物質, 腫瘍周辺部の破骨細胞の機能六進, あるい は骨の支配血管への腫瘍の圧迫，などにより骨芽細胞 に刺激が与えられ，骨芽細胞由来のオステオカルシン が上昇する可能性が考えられる。

骨腫瘍患者の血中オステオカルシンは, 結果の項で 示したごとく，健康人に比べて高く，なかでも転移性 骨腫瘍や骨髄腫の高 $\mathrm{Ca}$ 血症では血中 ALP や $\mathrm{LDH}$ の上昇とともに，オステオカルシンも高くなり，直接 的あるいは間接的な因子により骨芽細胞が刺激を受け たものと思われる。

腫瘍患者における骨からの Ca 動員作用として, 
local osteolytic hypercalcemia (主に osteoclast-activating factor や prostaglandin $\left.\mathrm{E}_{2} な と ゙\right)^{2), 3)}$ や humoral hypercalcemia of malingnancy (PTH 様物質, 1.25 $(\mathrm{OH})_{2} \mathrm{D}_{3}$ あるいは transforming growth factor など) の関与4)-7) が報告されている。またこれら疾患では, 循環血流量の減少, 糸球体乃過率の減少, $\mathrm{Ca}$ の尿細 管での再吸収え進，などにより高 Ca 血症になるとい われている(3)。しかし，骨腫瘍疾患における高 Ca 血 症の機序ははっきりと確立されていないが, 腫瘍細胞 によって骨回転を促進させている可能性も十分考えら れる。また, 結果の項で示したごとく, 明らかに健康 人に比べ, 骨腫瘍患者の血中オステオカルシンが上昇 していたことは骨腫場からの骨芽細胞の刺激因子の存 在する可能性がうかがえる。

以上のことより，血中オステオカルシンを測定する ことは骨腫瘍患者の生化学的な指標となり, とくに骨 尰瘍患者の高 $\mathrm{Ca}$ 血症に扣いてはこれら疾患の診断な らびに治療効果の判定に利用し得る可能性のあること が示唆された。

\section{文献}

1) Mundy, G.R. and Martin, T.J.: Metabolism, 31, 1247-1277 (1982)

2) Dewhirst, F.E., Stashenko, P.P., Mole, J.E. and Tsurumachi, T.: J. Immunol., 135, 25622568 (1985)

3) Minkin, C., Fredericks, R.S., Pokress, S. et al.: J. Clin. Endocrinol. Metab., 53, 941-947 (1981)

4) Linehan, W.M., Kish, M.L., Chen, S.L. et al.: J. Urol., 135, 616-620 (1986)

5) Stewart, A.F., Insogna, K.L., Goltzman, D. and Broadus, A.E.: Proc. Natl. Acad. Sci. USA, 80, 1454-1458 (1983)

6) Rosenthal, N., Insogna, K.L., Godsall, J.W. et al.: J. Clin. Endocrinol. Metab., 60, 29-33
(1985)

7) Ibbotson, K.J., D'Souza, S.M., Ng, K.W. et al.: Science, 221, 1292-1294 (1983)

8) Price, P.A., Parthemore, J.G. and Deftos, L.J. : J. Clin. Invest., 66, 878-883 (1980)

9）鳥住和民, 山田龍作, 岡本幸春, 他 : Radioisotopes, 35, 482-485 (1986)

10）鳥住和民，木浦賀文，上好昭孝，他 : ibid., 35, 645-647 (1986)

11）奥 浩子, 大田喜一郎：ホルモンと臨床，35, 1023-1026 (1987)

12) Payne, R.B., Little, A.J., William, R.B. et al. Brit. Med. J., 4, 643-646 (1973)

13) Ralston, H.S., Gardner, D.M., Jenkins, S.A. et al. : $B A M, 2,227-242$ (1987)

\section{Abstract}

Clinical Evaluation of Osteocalcin in Sera of the Patients with Neoplasmas of Bone. Kazutami ToRIZUMI, Akitaka UEYOSHI*, Masayuki YASUI**, Eiji SHIMIZU***, Yukiharu OKAMOTO***, Tadaaki TUDA*** and Kiichiro OTA***: Department of Radiology, *Department of Orthopedics, **Department of Neuro-psychiatry, ***Department of Laboratory Medicine, Wakayama Medical College, 1, Nanaban-cho, Wakayama-shi 640, Japan.

The clinical significance of osteocalcin in sera of bone tumors were measured in sera of various kinds of bone tumors. The levels of osteocalcin were higher in bone tumors than those in normal subjects. Serum osteocalcin levels in hypercalcemic groups of bone metastasis and myeloma showed a remarkable increase in a parallelism with serum $A L P$ and LDH levels. These results suggested to be directly or indirectly activated on osteoblast by bone tumors and to be synthesized osteocalcin in osteoblast.

(Received January 18, 1988) 